\title{
THE ROLE OF MICROFINANCE IN THE RURAL DEVELOPMENT PROCESS; CASE STUDY OF TANDEM HILIR II VILLAGE, HAMPARAN PERAK SUB DISTRICT, DISTRICT OF DELI SERDANG
}

\author{
Iswanto \\ Magister of Development Study \\ North Sumatera University \\ Medan, Indonesia
}

\author{
Dadang Darmawan \\ Faculty of Social and Political Siences \\ North Sumatera University \\ Medan, Indonesia
}

\begin{abstract}
The potential of community fundraising in the villages through microfinance is actually very large, the through of institution of informal and semi-formal microfinance that is managed by the community itself, such as: credit unions, womens microfinance groups, grameen banks and "arisan" or "jula-jula" (the local tradition of micrifinance). The influence of microfinance so far is still limited to help the community in overcoming the risk of relative vulnerability level and small business activity in the scale is still very limited. Claims on the success of the microfinance program as a model of village development and helping the poor from the poorest are not proven. The position of microfinance has not been able to speak much; its influence is still very small in the rural development proces $t$ in the village. Management of the microfinance institutions is still limited to small groups that are separate and have not been able to be assembled into a larger and stronger group at the village level with a wide range.
\end{abstract}

Keywords- microfinance, rural development process, empowerment.

\section{INTRODUCTION}

The rural development are generally refers to the process of how to improve the quality of life and welfare of people living in villages areas that are relatively isolated and sparsely populated. Traditionally the life of rural communities is based on nature, by cultivating natural resources such as agriculture and fishermen. However, with changes in global production networks those are usually centered in cities, leading rural communities to urbanization. This has its own impact and contributes to change the character of rural areas. In general, rural life is characterized by the large number of people living in poverty, and only a handful of group are established and wealthy.

Several field findings show that productive in agricultural and fishing have changed owner to the urban capitalis or cities capitalis. The agriculture lands have turned into plantations, such as palm oil, cocoa and rubber plantations. The land has changed owner and is owned by the cities. While in the fishing sector such as keramba (basket put in a stream for raising fish) and earthen dam, the owners are't urban areas but owner changed cities. The life of the fishermen is depended form capitalis fishing sector such as the procurement of fishing and marketing of fish

The many people from rural is economic dependent to be labor in city and working from rural capitalis. This can be understood, because building and developing productive businesses require large capital. While the owner of the capital is the city people or a handful of people who live in his village. On the other hand, they are also far from access to credit; it is because they do not have formal prerequisites such as collateral to gain access to credit.

The problem of rural development are actually very complex, and not just a matter of capital only. Cultural factors and the destruction of the social system of the village community such as waning of mutual sharing decreased solidarity, the destruction of social institutions such as village barns, the growing individualistic, the transformation of social relations into commercial relations and the waning of the serving spirit.

Development objectives in rural development areas should also cover the four main elements in a synergistic way, namely economic development, social development, infrastructure development, and environmental sustainability development. The needs of rural communities towards a broader development approach model and focus on development goals that not only generate added value from agriculture, marine and natural resource-based enterprises. Rural development should also emphasize local production as a rural economic development strategy, reviving social values and synergizing with nature.

Some believe that one way to break of the vicious circle of poverty is to provide capital to the poor. Furthermore, the community is encouraged to be able to conduct capital formation. The meaning of capital formation here is that the community does not carry out its entire activities at this time 
simply to meet the urgent needs and wants of consumption, but directs part of it for the manufacture of capital goods, tools and equipment, machinery and transport facilities, factories and equipment. Thus the definition of capital here has is the supply of factors of production that can be physically reproducible. And if the stock of capital rises within a certain time limit then this is called the accumulation of capital or capital formation.

Microfinance has been recognized as a financial service that is able to reach vulnerable groups from the poorest of the poor. Because the target group that becomes their service choice is precisely to the most vulnerable groups of the poor and the the poor of poorest. Martin \& Rutherford (2002) explain that microfinance services are the poorest of the poor or the poor. Such a thing cannot be done by commercial formal financial institutions.

Robinson (2001) proves that microfinance services can help the poor in developing businesses and increasing income, improving quality of life, helping with severe difficulties, and increasing confidence. However, he also acknowledged that the successful customers are some of the minority that are economically active and have access to services from microfinance institutions. The most developing countries do not yet have the opportunity to build microfinance that can help poor clients build their companies, increase their income, care for their families, and develop confidence.

The success of a certain level of microfinance program schemes in fighting poverty has proved to be a considerable influence among donors, community development practitioners and academics. Further, even the government is also trying to develop a similar scheme, namely by giving aid to the poor by providing revolving group loans, such as aid schemes that are distributed to the women microfiance group (koperasi simpan pinjam perempuan). John Weiss, Heather Montgomery and Elvira Kurmanaliena (2003), in studies conducted in several countries in Asia including Indonesia, show that microfinance services have been enough to help the poorest of the poor, such as increased incomes and participation in development programs.

The report of "Banking with the Poor Network" (2009), indicates that there are significant developments by microfinance providers in Indonesia. However, there is still unmet demand for microfinance services, where the majority of rural households still do not have access to funding sources from semi-formal or formal institutions. Regulated microfinance providers, such as commercial banks and rural banks (BPRs) are only able to serve at the upper level of the micro business market, ie in the district or sub district. While Non-Governmental Organizations, cooperatives and Village Credit Banks (BKD) reach lower level to the bottom, but have limitations to reach remote areas.

\section{THE LIFE OF RURAL CUMMUNITY}

The rural communities of Tamdem Hilir II village mostly depend on their life by working as farmers. They cultivated 789.7 ha of agricultural land, divided into 2 acres, namely for rice fields of 764.7 ha and for plantations covering 25 ha. A total of 358 ha is a rice field with $1 / 2$ technical irrigation, and the rest is a rain-fed rice field, which is 406.7 ha. While the dry land that is as much as 25 ha used as a garden plant area. Of the total 2,456 heads of the Tandem Hilir II village family, only 1,249 families own agricultural land, the rest only have home tents with yards less than $400 \mathrm{~m} 2$. While the villagers who have an agricultural area with an area of 5-10 ha is 40 people. See the following table:

Table 1. Data of Head of Family by Work

\begin{tabular}{|c|l|c|}
\hline Number & \multicolumn{1}{|c|}{ Type of work } & Amount \\
\hline 1 & Farmers & 1003 Family \\
\hline 2 & Merchants & 450 Family \\
\hline 3 & $\begin{array}{l}\text { Government } \\
\text { employees }\end{array}$ & 84 Family \\
\hline 4 & Labor & 982 Family \\
\hline 5 & Other & 63 Family \\
\hline \multicolumn{2}{|l}{ Amount } \\
\hline
\end{tabular}

Source: Profile of Tandem Hilir II Village, 2012

In the "Rural Development: Putting the Last First", Chambers (1987) proposes the concept of deprivation trap. Robert Chambers analyzes the causes of poverty as interrelated causal relationships of powerlessness, vulnerability, physical weakness, poverty, and isolation, see the following diagram:

\section{Diagram 1. Flow Chart of Causes of Poverty}

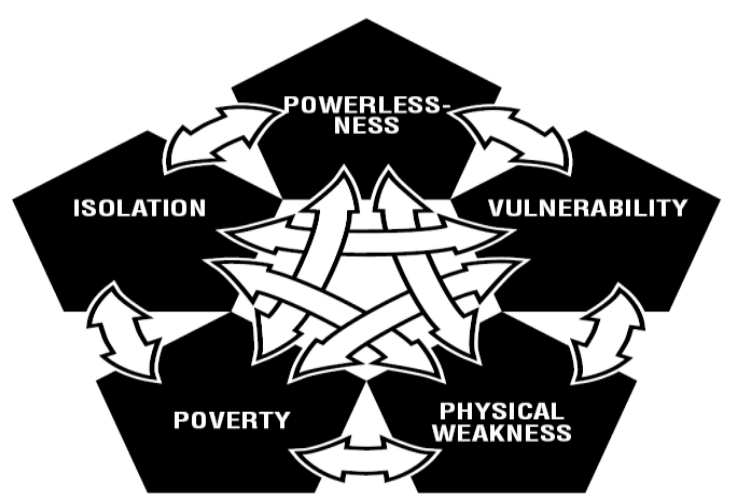

Based on the objective condition of Tandem Hilir II villagers, the level of vulnerability of the community is mostly caused by powerlessness, vulnerability and there are small in isolation position. The mapped of community lives in Tandem Hilir II on the basis of poverty levels, at least the community can be grouped into 4 (four) groups: extremely poor, very poor, middle poor and not poor but in vulnerable positions.

Tebel 2. The Profile of Poors Village

\begin{tabular}{|c|l|c|}
\hline Number & Category of Poor & Amount \\
\hline 1 & Extremely poors & 7 Family \\
\hline 2 & Very poors & 23 Family \\
\hline 3 & Medium Poors & 409 Family \\
\hline 4 & Vulnarables & 375 Family \\
\hline \multicolumn{2}{|c|}{ Amount } & 814 Family \\
\hline
\end{tabular}

Source: Processed from the village government data, interviews with community and observations on the lives of Tandem Hilir II village

Village communities who are in the category of poor and very poor, usually untouched by development programs. 
Generally they only get charity program services like; Raskin (hulled rice for poors) and direct money cash aids (BLT) from the government. They cannot participate in the development a program because of some things other than the very low quality of human resources, as well as the whole family has been deployed to work. The absence of physical assets such as agricultural land is also a constraint, the government's development programs are generally for land-owning farmers.

Such circumstances make them isolated, in which access to development programs is closed to them. They are rural societies, who in Chambers terms (1987) are the most "unseen" and "unknown". Based on data from village government of Tandem Hilir II, poor people are 814 families. Of these, the extremely poor are not too many in the village. Only around 7 families of urban comunities who fall into the category of extremely poor, while the community who are in very poor category about 23 families.

The vulnerable poor are citizens who lack the ability to deal with shocks and rapid and sudden changes such as crop failures, sick families or others. They will quickly fall into a position of poor or very poor. This vulnerability causes them to be around a poverty line that changes their status, they can also be grouped in transient poverty. They can be classified as a poor group of people who are in the vulnerability category.

Indeed, motivation and work ethic of Tandem Hilir II village community is good enough in the land productively owned. However, this motivation and work ethic is not supported by good creativity and management. The type of knowledge and skills that rural community have in general is still very limited to the work of agricultural land cultivation, breed with tchnic and conventional knowledge, and small household industries. In the end there is not much employment created and still rely on old production systems, such as farming and working part-time.

The process of pouperization and asset tranfer process the village stems from the adjustment of work while experiencing a vulnerable situation, and if it is not resolved then it will reduce the number of meals. If it also does not recognize, then he will consume food reserves, such as reserve funds for seeds and cultivate agricultural land, an then sell of animal livestock. The next actions is boorow money from big family, neighbors or renternir (personal creditor). Due to trapped debt, eventually selling production assets such as motorcycles, water machines for agricultural irrigation or farm equipment, and to rent agricultural production land. If the situation becomes more difficult, then it is continued by selling agricultural land and houses, and will eventually migrate permanently to other places.

\section{MiCROFINANCE TO OVERCOME VULNERABILITY}

Discussion of the role of microfinance services in community life in the village of Tandem Hilir II cannot be done properly when it does not start from knowing who the poor and poor of the poorest community in the village. How the group manages risks in the face of shocks and events of compelling economic pressures, while simultaneously spending money that is not yet available. If the villagers mapped the lives of the villagers on the basis of poverty such as extremely poor, very poor, medium poor, and vulnerable positions.

Mechanism of rural community in survival at the time of the shock is to optimize resources or family assets to overcome the shocks from employing all family members to work or production adjustments, reducing the number of meals, selling animal livestock, renting land, selling land, and selling homes. The shocks and economic pressures force them to spend money that is not yet available, such as for daily feeding, treatment for sick family members, and school fees for their children.

Risk factors that many villagee communities face and cause them in vulnerable positions include seasonality, inflation, weather behavior and unexpected emergencies such as illness, sudden death of family members, job loss, fire and theft. Then other high cost factors associated with life cycle events such as weddings, birth feasts, and children's education have contributed to the dragging of societies falling into poverty.

It is in this context that a substantial role of microfinance is great in helping the poor in the village. Financial services from microfinance by providing a way for poor households to access credit and increasing small savings into larger ones are extremely beneficial in reducing vulnerability. The result is that many poor rural communities are helped in facing the risk of calamities and shocks that befall them. Once the shock or event of pressure occurs, the rural communities then take advantage of various coping strategies such as reducing consumption, increasing income by employing labor or selling assets, attracting unofficial or official savings, and cashing in bills stemming from unofficial group-based insurance mechanisms.

Funds obtained through formal, semi-formal or informal financial institutions such as credit unions (CUs), women's microfinance groups (SPP), "arisan" or "jula-jula" (the local tradition of microfinance) are used for three things: first, addressing urgent important needs such as school fees, party fees, and medical expenses. Second, used for production activities. Third, used for consumption.

Access to financial services from microfinance in the village is actually not able to reach the lowest level of reaching out to the extremely poor and very poor. Those who are able to access microfinance services, both informal and formal can only reach the medium poor and vulnerable. Rural communities who are in extremely poor and very poor category generally have no prerequisite for access, even from informal microfinance institutions such as "arisan" or "jula-jula" (the local tradition of microfinance). Family income that is only enough to eat on that day, does not allow them to join the "arisan" or" jula-jula" which requires the existence of regular funds although the amount is small. Generally their children are no longer schooling and deployed to work even with very little wages. This is what makes their confidence low and does not care about the various forms of development programs.

\section{MiCROFINANCE FOR SMALL BUSINESS}

Successful claims of microfinance programs, whether demonstrated by research into the role of microfinance or by microfinance sreams actually stem from two things: First, which microfinance is able to provide credit services to 
families and poor communities that are not able to reach by banks. Secon,credit funds from microfinance services are used for small business activities.

Target groups of microfinance services from poor groups in the community, such as farmers, fishermen, ranchers or shepherds, small and medium entrepreneurs who have produced, recycling, electronic reps, small workshops, carpenters, driver. The credit services are provided to groups or individuals, with the principle of assisting them to meet various needs in building and developing businesses, consumption, personal needs, social needs and developing physical assets such as factories, cattle stalls, fish ponds, kiosks and homes. Credit services to poor families have not yet been based on potential mapping and good planning process. Thus the service products have not been able to meet the needs of rural communities, especially in the medium and long term.

Carefulness in understanding the risks and vulnerabilities of the poor is a way to understand the possibilities and limitations of the equivalent of poverty with microfinance institutions. Attention should be directed to the income-generating dimension of poor families and how they use these financial services to build physical, financial, human and social assets, reduce risk, and reduce vulnerability.

Extremely poor and very poor families are residents who are still out of reach of microfinance services. The majority of urban communities who use both formal and informal microfinance services are from the medium poor, vulnerable and middle-class villages. The drivers of financial services in villages such as credit unions and women microfinance group $\mathrm{s}$ (SPP) mostly come from middle-class villagers and vulnerable groups. The same is true of "arisan" or "jula-jula". The vulnerable group of middle-income villagers is the most significant segment of the microfinance program in the village.

\section{MiCROFInANCE FOR CONSUMPTION}

Consumption activity is unproductive; therefore the use of funds from microfinance financial services can be reduced so as not to fall for consumption activities. Even if forced to do, it is to overcome shock and meet basic needs to eat. In this context, consumption activity can be divided into two. First, consumption activities to meet basic needs of food, clothing and housing (basic needs). Second, the activity of consumption to meet the pleasure, follow the trend, and pride. The fundamental difference between these two activities is that consumption activity to meet needs is based on the needs analysis, while the second type of consumption activity is based on an analysis of pleasure.

This sorting is very difficult to do at the operational level; this is because the needs of each person is different from each other, so is also in the case of pleasure. This sorting can actually be done using the needs analysis. This will separate where the actual needs and where the pleasure. This sorting is a key element in community development; most rural communities are trapped to spend their money on things that are not really needed. Their life behavior is determined by their image and lifestyle, following the latest trends, and buying items based on prestige and not its function. In the end what happens is waste and not at all productive. This kind of disease also infects the people of Tandem Hilir II village.

The use of microfinance services funds in addition to meeting basic needs and production is also used for consumption activities. The general behavior of citizens at the time of obtaining funding from microfinance institutions such as withdrawing savings in credit union and women's microfinance groups and getting "jula-jula or arisan", part of the money is also used to buy daily food quality better than ordinary days, such as buying meat, fish, or bring family members to eat together at the restaurant. It is also used to build or repair homes, motorcycle credit advances, buy a refrigerator, mobile phone, a set of desk chairs, cabinets, and bedding.

\section{THE INFLUENCE OF MICROFINANCE IN RURAL DEVELOPMENT PROCESS}

Microfinance institutions operating in Tandem Hilir II Village can be divided into two types: microfinance institutions built and managed by the community and microfinance institutions coming from outside. Microfinance institutions managed by the community include credit unions, women's microfinance groups (SPP) and" arisan or jula-jula". Financial institutions that come from the village area are Pokmas Mandiri (grameen bank), Eka Prasetya Rural Bank (BPR), and People's Business Credit (KUR) from Bank Rakyat Indonesia. A similar program was developed by PNPM Mandiri (national program for rural development from government) under the name womens microfinance groups (SPP). The same system is joint responsibility, only difference between one group of 10 people and at the same time become the guarantor among group members. Here is the SPP group in Tandem Hilir II village, see table 3 .

Table 3. Women's Microfinance Groups

\begin{tabular}{|c|l|c|}
\hline Number & \multicolumn{1}{|c|}{ Name of Groups } & Amount \\
\hline 1 & Bunga Abadi & 10 person \\
\hline 2 & Mandiri & 10 person \\
\hline 3 & Melati & 10 person \\
\hline 4 & Kemuning & 10 person \\
\hline 5 & Delima & 10 person \\
\hline 6 & Anggrek & 10 person \\
\hline \multicolumn{2}{|l|}{ Amount } & $\mathbf{6 0}$ orang \\
\hline
\end{tabular}

Source: The Group of Women Mincofinane in Tandem Hilir II Village

Indeed the potential source of public funds for financing the development in the village is very large. The result of analysis on the existence of microfinance in the village shows that the source of funds collected through "arisan or jula-jula" activities and credit unión is very big. Arisan or jula-jula funds if collected in one month can reach Rp 619.000.000, -, then credit union funds reach Rp. 208.000.000, -. This does not include funds from gremeen bank from thePokmas Mandiri and womens micofinance groups from the PNPM Mandiri program. This does not include credit funds from the People's Business Credit program (KUR) of Bank BRI or other banks. In each hamlet, there are at least five families who can access 
the BRI KUR funds. The problem faced by the residents is that the funds can not be mobilized for larger joint productive activities such as to build business cooperatives or other business activities. See the table below.

Table 4. Groups of Credit Union in Tandem Hilir II Village

\begin{tabular}{|c|l|l|r|}
\hline No & \multicolumn{1}{|c|}{$\begin{array}{c}\text { Name of } \\
\text { Group }\end{array}$} & Mamber & Omset \\
\hline 1 & Berkah & 67 person & $60.000 .000,-$ \\
\hline 2 & Karya Bakti & 57 person & $50.000,000,-$ \\
\hline 3 & Tanjung Sari & 69 person & $45.000,000,-$ \\
\hline 4 & Bina Tani & 13 person & $49.000,000,-$ \\
\hline 5 & $\begin{array}{c}\text { Wanita Tani } \\
\text { Berkat Rukun }\end{array}$ & 27 person & $4.000,000,-$ \\
\hline \multicolumn{3}{|c|}{ Total } & $\mathbf{2 0 8 . 0 0 0 . 0 0 0 , -}$ \\
\hline
\end{tabular}

Source: Group of Credit Union in Tandem Hilir II Village

Table 5. Number of Arisan (jula-jula) Money in Tandem Hilir II Village

\begin{tabular}{|l|c|c|r|r|}
\hline \multicolumn{1}{|c|}{$\begin{array}{c}\text { Tipe of } \\
\text { Arisan }\end{array}$} & $\begin{array}{c}\text { Mamber } \\
\text { of } \\
\text { Person }\end{array}$ & Group & \multicolumn{1}{c|}{$\begin{array}{c}\text { Total } \\
\text { money / } \\
\text { person }\end{array}$} & \multicolumn{1}{c|}{$\begin{array}{c}\text { Amount in } \\
\text { month }\end{array}$} \\
\hline $1000 /$ days & 170 & 1 & $1.700 .000,-$ & $51.000 .000,-$ \\
\hline $2000 /$ days & 110 & 4 & $2.200 .000,-$ & $264.000 .000,-$ \\
\hline $30.000 /$ weeks & 20 & 2 & $6.000 .000,-$ & $48.000 .000,-$ \\
\hline $50.000 /$ weeks & 80 & 1 & $4.000 .000,-$ & $160.000 .000,-$ \\
\hline $\begin{array}{l}\text { 200.000/ } \\
\text { weeks }\end{array}$ & 60 & 1 & $12.000 .000,-$ & $48.000 .000,-$ \\
\hline $\begin{array}{l}300.000 / \\
\text { weeks }\end{array}$ & 40 & 1 & $12.000 .000,-$ & $48.000 .000,-$ \\
\hline \multicolumn{5}{|c|}{ Amount in month } \\
\hline
\end{tabular}

Sounce: Rural Community in Tandem Hilir II Village

So far, rural cummunities using funds from microfinance services are still limited to overcome vulnerability, even if used for productive activities the percentage is still small. Many productive activities are supported by the capital of failed microfinance institutions. Failure is due to several things: First, the absence of good business planning. Second, the absence of entrepreneurship. Generally, rural communities in starting a productive business, still experimental and follow-up, and not accompanied by the ability to recognize business risk factors. In the end many businesses are failing in the middle of the road.

In the context of rural development process, microfinance institutions have not been able to bring the community to selfreliance such as: increased savings and investment, productive growth, strong and independent microfinancial institutions in village. The role of microfinance institutions in rural areas is still limited to self-defense: to overcome the vulnerabilities arising from unpredictable seasons, inflation, and unforeseen emergencies such as illness, sudden death of family members, loss of employment, fire and theft . Then other high costs associated with life cycle events such as weddings, birth parties, circumcision parties, and tuition fees. Some of these funds are used by communities to cope with sudden changes and situations that bring them in vulnerable positions.
During this time the extemely poor and very poor are the people who cannot access the program of rural development from goverment. This is because they do not have adequate resources and other assets such as agricultural land which is usually a prerequisite for accessing the program. The village crisis resilience institutions can cover the gap by providing them with social and educational assistance. Thus in time they will be able to participate in subsequent development programs.

\section{CONCLUSION}

The development of microfinance in Tandem Hilir II Village has been ups and downs, yet the community has a strong culture and potentially developed to build a much bigger and stronger microfinance. The type of microfinance that develops varies considerably, from informal as in formal or "arisan or jula-jula "and "renternir (personal creditor)", semi formal such as credit union (CU), women's microfinance groups (SPP), and to formal microfinance developed by commercial bank institutions such as Bank Rakyat Indonesian (national goverment bank) through People's Business Credit (KUR), Bank Sumut (province goverment bank), Bank Mandiri (national goverment bank), and Bank Perkreditan Rakyat (swasta bank).

The use of funds from microfinance financial institutions by the community includes three things: addressing vulnerability, production activities, and consumption. His position is still in a position to help residents to survive a crisis or shock that can bring people mired in further poverty. Generally rural communities use funds from microfinance to deal with sudden life difficulties such as: difficulties arising from unpredictable seasons, inflation and unexpected emergencies such as illness, sudden death of family members, job loss, fire and theft. In addition it is used for other high costs associated with their life cycle events such as: weddings, births, circumcision, deaths of family members, and children's education. Many productive activities supported by the capital of microfinance turned out to be a lot of failures. This is because there is no good business plan and no entrepreneurial spirit.

Claims on the success of the microfinance program as a model of village development and helping to the poor from cateogiries of the extremely poors and very poors are in fact still in question. The results of the study show that access to microfinance services actually cannot reach the lowest level, namely: the extremely poors and very poors. Those who are able to access microfinance services, both informal and formal, are the most capable of reaching the medium poors, vulnerable poors and upper-middle class villages.

It shows that microfinance influence in village development is still relatively small, especially if it is related to the independence of rural development. The position of microfinance institutions has not been able to speak much. The presence of microfinance institutions that grow in villages such as Credit Union, women's microfinance groups (SPP), and "arisan or jula-jula" still run independently, have not been able to be collected as a greater force in building the village. 


\section{VIII.RECOMMENDATION}

The financial potential in the village is really big, it's just that the potential is still closed, because the rural communities are positioned as the weak and need help. Through certain approaches and methods, the potential can be explored, built and developed as an important force in rural development. Microfinance can serve as an entrance that is able to encourage the spirit of ruraal communities to particitation inrural development. Semi-formal microfinance institutions, such as long-established credit unions in the village, can be galvanized and organized into larger and wider scopes and become formal institutions that are legally recognized by the government. With the expansion of the area and an increase in the number of financial assets, it is possible to build larger joint productive enterprises, which impact on increasing the value of the members' incomes.

There is a need for rural assessments with complete and comprehensive before preparing and developing programs of rural development. An analysis capable of depicting the living reality of the hearts and minds of the rural communities, which includes the processes of society in meeting the needs, difficulties encountered, social relationships, successes, open opportunities, and expectations forward to live in a decent and prosperous way. The scheme of village development program should be a solution to answer the various objective problems faced by the rural community.

\section{REFERENCES}

[1] Aspers, Petrik; October 2009; Empirical Phenomenology: A Qualitative Research Approach; Indo-Pacific Journal of Phenomenology; Vol. 9; Edition 2

[2] Bradshaw, Ted K; 2006; Theories of Poverty and Anti-Poverty Programs in Community Development; Human and Community Development Department University of California; Rural Poverty Research Center Working Paper No. 06-05

[3] Chambers, Robert; 1995; The Poverty Livelihoods: Echoes Reality Coutts ?" in the Oner Kirdar dan Leonard Silk (Ed.) People: From Impoverishment to Empowerment; New York; New York University Press.

[4] --------------------; 2003; Rural Development: Putting the Last First, Longman, London, UK, page. 10

[5] ----------------; 1994; The Origin and Practice of Participatory Rural Appraisal, World Development, Vol. 22, No. 7

[6] -----------------; December 2007, Poverty Research: Methodologies, Mindsets and Multidimensionality, IDS Working Paper No. 293, London, Institute Development Studies

[7] Chamber, Robert and Conway, Gordon R; 1991; Sustainable Livelihood: Practical Concept for the 21st Century; IDS Discussion Paper 296

[8] Dos Santos, Theotonio; May, 1970; "The Structure of Dependence", in The American Economic Review, Vol. 60, No. 2, Paper and Proceeding of the Eighty - Second Annual Meeting of the American Economic Association, page. $231-236$.

[9] Ellis, Frank dan Biggs, Stephen; 2001; Evolving Themes in Rural Development 1950s-2000s; Development Policy Review; 19 (4); 347 448

[10] Edelman, Irma; 1980; Economic Development and Political Change in Developing Countries; Social Research: An International Quarterly, Vol. 47, No. 43
[11] Foster, John Bellamy; May 2007; The Imperialist Word System: Paul Baran's Political : Economy of Growth After Fifty Years; Monthly Review; 59, 1; Research Library

[12] Global Envision: the Confluence of Global Markets and Poverty Alleviation; April 2006; The History of microfinance; Acsess to $20 \mathrm{Mei}$ 2012

[13] Goodwin, Neva R; 2003; Five Kinds of Capital: Useful Concepts for Sustainable Development;, Global Development and Environment Institute Working Paper No. 03-07, Tufts University.

[14] Gunder Frank, Andre; 1970; "The Development of Underdevelopment", in Rhodes, F. Robert; Imperial and Underdevelopment; New York; Monthly Review Press.

[15] Kartodirdjo, Sartono; 1991; Method of Use of Document Materials; in Koentjaraningrat "Community Research Methods"; Gramedia; Jakarta

[16] Maleong, Lexy; 2006; Qualitative Research Methods, PT. Youth Rosada, Bandung

[17] Martin, M., Hulme; D. \& Rutherford, S.; 2002; Finance for the Poor: From Microcredit to Microfinancial Services; Journal of International Development; 14, 273 - 294

[18] Milles, MB \& Hubberman, AM, (1992); Qualitative Data Analysis; Translation by Tjetjep Rohidi and Mulyarto, UI Printing, Jakarta.

[19] Morgan;1979; Sociological Paradigms and Organizational Analysis: Elements of the sociology of corporate life; Heinemann Educational Books; London

[20] Nurkse, Regard, 1961, Problems Of Capital Formation In Underdeveloped Countries, New York, Oxford University Press

[21] Otero, Maria; 1999; Bringing Development Back, into Microfinance; Journal of Microfinance; 1 (1); 8 - 19

[22] Parr, John B; March 2001; On the Regional Dimensions of Rostow's Theory of Growth; RURDS Vol. 13, No. 1; University of Glasgow, Glasgow, UK

[23] Pezzey, John C.V and Toman, Michael A; January 2002; The Economics of Sustainability: A Review of Journal Articles; Resources for the Future; Discussion Paper 02-03

[24] Pollard, Jane; Mc Ewan, Cheryl; and Hughes, Alex (Edt.), 2011, Postcolonial Economies, Zed Books Ltd, London, UK

[25] Ritzer, George; 1992; Sociology of Dual Paredigm Science; Language translation by Alimandan; Rajawali Press; Jakarta

[26] Robinson, Marguerite S, May 2001, The Microfinance Revolution: Sustainable Finance for the Poor, Washington DC, Open Society Institute and World Bank

[27] Schreiner, M; 2001; Informal Finance and Designing of Microfinance; Development in Practice; Vol.11, No. 3

[28] Snowdon, Brian and Vane, Howard R; 2005; Modern Macroeconomics; Its Origins, Development and Current State; Edward Elgar Publishing Limited; Cheltenham, UK and Northampton, MA, USA

[29] Stake, Robert E; 2010; Qualitative Research: Studying How Things Work; The Guilford Pres; New York and London.

[30] Waber, Heloise; May 2004; The New Economy and Social Risk: Banking on the Poor; in Review of International Political Economy; Vol, 11 , No. 2

[31] Weiss, John, Montgomery, Heather dan Kurmanaliena, Elvira, (December 2003), Micro Finance and Poverty Reduction in Asia: What is the Evidence?, ADB Institute, Research Paper Series No. 53

[32] Woolcock, Michael and Narayan, Deepa; 2000; Social Capital: Implications for Development Theory, Research, and Policy; World Bank Research Observer Vol. 15 (2).

[33] Vincent Ferraro, 2008, "Dependency Theory: An Introduction," in Giorgio Second (Ed.), The Development Economics Reader, London: Routledge 